\title{
The Effect of the National Minimum Wage on the UK Small Business Sector: A Geographical Analysis
}

\author{
Colin M Mason, \\ Hunter Centre for Entrepreneurship, University of Strathclyde, Glasgow G1 1XH, \\ Scotland. colin.mason@strath.ac.uk, \\ Sara Carter \\ Department of Management and Organization, University of Stirling, Stirling FK9 \\ 4LA. sara.carter@stir.ac.uk \\ Stephen K Tagg \\ Department of Marketing, University of Strathclyde, Glasgow G1 1XH. \\ s.k.tagg@strath.ac.uk
}

\begin{abstract}
A national minimum wage (NMW) was introduced into the United Kingdom in 1999 as part of New Labour's active labour market approach. The level has been up-rated on several occasions since then. Most research suggests that the NMW has benefited low paid workers while having little adverse impact on employment levels. This paper explores the regional impact of the NMW on the small business sector, using data from the Federation of Small Businesses' biennial survey, the largest business survey in the UK. Overall, just over 21 per cent of businesses with employees up-rated employees and just under 10 per cent of employees have benefited from pay up-rates. The impact has varied across industries, with the greatest effects in the Hotels and Catering sector. In general, affected businesses have anticipated that they would be able to absorb the costs, although in some cases at the expense of a slight decline in profitability. The impact of the NMW also varies across the regions, having the least impact in London and the South East and the greatest impact in 'the north'. In the northern regions, businesses are less able to absorb the increased costs and more likely to respond by increasing prices. This has potential implications for the competitiveness of SMEs in these regions, which is more likely to be based around price and cost advantages than their counterparts in the south. The Low Pay Commission therefore should give greater attention to the geographical impacts of the National Minimum Wage in its evaluations and when proposing future increases in the rate.
\end{abstract}

Keywords: Geographies of labour; Low pay; National Minimum Wage; Small Firms; North-south divide 


\section{Introduction}

Over the last twenty years there has been a re-orientation of labour market policy in developed economies away from a passive, demand-oriented approach based on the payment of unemployment and other benefits, in favour of an active supply-side, involving measures to help the jobless back into employment (Robinson, 2000). Some commentators have labelled this development 'the rise of the workfare state' (Peck and Theodore, 2000; Martin et al., 2003). The central features of this approach are: first, measures to enhance the job search; second, an emphasis on enhancing employability through training and education to raise skills; third, a 'workfare' system in which social benefits are no longer an entitlement but are conditional, requiring a search for work and the acceptance of available vacancies or the compulsory participation in state subsidised work and training schemes; fourth, the introduction of initiatives to 'make work pay', notably tax credits and a minimum wage; and finally, the decentralisation of regulatory power to the local level (Dickens et al, 2000; Martin, 2000; Martin and Morrison, 2003). This approach is intended to have several benefits: in the context of record levels of employment and low unemployment, to enable the economy to function at higher aggregate employment levels without creating inflationary pressures; to cut public expenditure on welfare support by getting disadvantaged individuals into or back to work; to reduce welfare dependency; and to alleviate social problems that arise from the exclusion of individuals from the labour market. In short, the approach is guided by the principle that it is better to pay people to work than pay them not to work.

The US has led the way in this new model of labour market regulation. However, many of the features of the US system have been copied by the Labour Government 
through a "fast policy transfer" between policy elites (Peck and Theodore, 2000: 429), notably workfare schemes (the New Deal), employability initiatives (e.g. Employment Zones) and initiatives that 'make work pay' (notably the working families tax credits for low income families and a national minimum wage) (Haughton et al, 2000; Peck and Theodore, 2000; Sunley et al, 2001; Fergusson, 2002.)

This paper is concerned with the UK's National Minimum Wage (NMW) which, as the OECD (2003) has recently observed, must form a key part of any active labour market policy "tool box" that seeks to move those on low income from benefits to employment by "making work pay". Its importance is twofold. First, low entry wages have important implications for work incentives. Groups with high out-of-work benefits (typically those with children or high housing costs) are often little better off in work than out (Dickens et al, 2000). Second, a national minimum wage is essential to underpin a system of in-work benefits designed to make work more attractive and reduce the benefits trap by increasing the financial gain from employment compared with out-of-work income. Without a legal floor to wages, the benefits system would subsidise low paying employers and large numbers of low-paid employees with families would become entitled to means-tested in-work benefits at ever-rising costs to the Exchequer (Sutherland, 2001). The National Minimum Wage was therefore an essential component in the Labour Government's ambitious strategy of reforming the tax and benefit system to encourage the jobless back to work and reduce family poverty (Brown, 2002).

Britain has a history of statutory legislation of wages. Throughout the $20^{\text {th }}$ century, Wages Councils and their predecessors set minimum wages in specific low paying 
sectors (Metcalf, 1999). Such measures were viewed as obstacles to job creation by successive Conservative Governments, and were abolished in 1993 as part of a deregulation approach to labour market policy (although Dickens and Manning (2004) suggest that they were viewed as largely ineffective). The 1997 Labour Party manifesto included a commitment to establish a National Minimum Wage. Two months after their electoral success, an independent Low Pay Commission (LPC) was created to turn this commitment into a workable policy. ${ }^{1}$ Its key tasks were to set the level of the Minimum Wage, the size of its subsequent up-rating and decide whether a separate rate should be applied for younger workers (Brown, 2002). Its first report (Low Pay Commission, 1998) formed the basis for the NMW that was introduced in April 1999. The adult hourly rate was set at $£ 3.60$, with a lower rate of $£ 3.00$ per hour for those aged $18-21 .^{2}$ In setting the rate, the LPC took into account international comparisons, potential wage inflation effects (and possible action by the Monetary Policy Committee of the Bank of England on interest rates), and knock-on effects via wage differentials. The lower youth rate was established because of concern that the NMW would lead to youth unemployment if set too high (Metcalf, 1999). The NMW directly benefited $1.2 \mathrm{~m}$ workers, 6 per cent of the workforce, and resulted in an increase of 0.25 per cent in the national wage bill (Metcalf, 2002). ${ }^{3}$ The main beneficiaries have been part-time workers, women, home-workers, lone parents in work, and non-white workers. The two main industry sectors affected have been

\footnotetext{
${ }^{1}$ See Metcalf $(1999 ; 2002)$ and Brown (2002) for discussions of how the Low Pay Commission operated.

${ }^{2}$ The LPC proposed that the youth rate should be set at $£ 3.20$ and apply to $18-20$ year olds, but this was subsequently amended due to Treasury concern both about the effect on youth unemployment and the resultant implications for the administration and funding of the New Deal programme (Metcalf, 1999). "Ideally the Chancellor would have liked a lower youth rate up to and including age 24, in line with the age profile of income support" (Metcalf, 1999: F60).

${ }^{3}$ The LPC initially anticipated the NMW to cover $2 \mathrm{~m}$ workers, 8.5 per cent of the workforce, and result in 0.6 per cent rise in wage costs. Data limitations subsequently revealed that actual coverage was lower; it would have required the NMW to be set at $£ 3.90$ to have achieved the anticipated coverage (Metcalf, 2002).
} 
retailing and hospitality, which together account for two-fifths of low-paid workers (Metcalf, 1999). Other disproportionately affected industries affected include security, cleaning, hairdressing, childcare, social care, horticulture, and clothing and footwear (Metcalf, 1999). (Also see Low Pay Commission, 2001; 2003; 2005)

Without an up-rating mechanism the real value of a minimum wage will fall over time. Moreover, as most welfare benefits are up-rated annually, the failure of a minimum wage to maintain its value in relation to welfare payments will lead to an increase in the size of the poverty trap (Sachdev, 2003). However, irregular large hikes in the value of a minimum wage will, by increasing its 'shock' effect, make it harder for businesses to adjust. From 1999 to 2002 the value of the NMW rose roughly in line with average earnings. However, on the recommendation of the LPC, in 2003 it was increased by double the annual earnings index to $£ 4.50$, with a similar size of increase in 2004 to $£ 4.85$. At this level the NMW was, for the first time, worth more in real terms than when it was introduced (Financial Times, 2004), equivalent to $40 \%$ of the average wage compared with $37 \%$ in 1999 (Financial Times, 2005a). The LPC has also recommended above annual earnings index increases for 2005 and 2006 (Table 1): their recommendation of a level of $£ 5.05$ from October 2005 was accepted by the Government and has now been implemented, but the proposal to raise this to $£ 5.35$ from October $2006^{4}$ is subject to economic conditions will be re-assessed by Government nearer the time. A new minimum wage for 16 and 17 year olds (excluding apprentices) of $£ 3$ has also come into effect in October 2005 to prevent these workers from being exploited (Financial Times, 2004). This gradual ratcheting up in the real value of the NMW since 2003 reflects the LPC's view that it "has been

\footnotetext{
${ }^{4}$ By 2006 the minimum wage in the UK will be virtually twice the current minimum wage in the USA (\$5.15, £2.70) (Financial Times, 2005b).
} 
a success. The economy has continued to generate new jobs, including the main lowpaying sectors, without any signs of an emergence of wage inflation. Many low paid workers have benefited ... [and] ... the impact on aggregate and sectoral wage bills has been minimal" (Low Pay Commission, 2005: 171). Metcalf (2002: 580) goes on to suggest that "it is plausible that around 2006 when, subject to economic conditions at the time the national minimum wage will have been up-rated by more than the growth in average earnings for four successive years, the national minimum wage will be about right relative to the median or mean pay distribution. Then indexing with a periodic review might be seriously considered."

\section{TABLE 1 ABOUT HERE}

The level at which a minimum wage is set is crucial in determining its economic and social impact. Assessing the employment impacts of a statutory minimum wage are viewed by some observers as "one of the most contentious policy questions in economics" (Stewart, 2002: 585). Conventional economic theory suggests that under perfect competition, with each worker receiving the value of his or her marginal revenue product of labour, a wage floor in the form of a mandatory minimum wage that is higher than the equilibrium wage will result in fewer workers being hired than are willing to work (Levin-Waldman, 2002). However, the empirical evidence has been equivocal. On the one hand, various studies have found that a minimum wage is associated with a decline in the employment of low paid workers (c.f. Deere et al, 1995; Pereira, 2001; Bazen and Marimoutou, 2002; Neumark et al, 2004). Other studies, however, notably the work of Card (1992) and Card and Krueger (1994; 1995), suggest that a minimum wage does not have an adverse effect on employment. 
This conclusion is inconsistent with the competitive labour market model, but possibly compatible with a monopsony model arising from such factors as turnover costs, imperfect information, search frictions and inertia which give firms some degree of market power in the labour market. On the other hand, critics suggest that such negative findings concerning the impact of the NMW can be explained by specific circumstances. For example, Deere et al (1995: 236) comment that "minimum wage responses are swamped by the broader trends of increasing labour market participation of women and employment expansion in the south and west [of the USA] where wages are lower." Others have argued that findings are sensitive to methodologies. Bazen and Marimoutou (2002), for example, suggest that long run, time series data are more likely to show negative effects of a minimum wage than cross sectional and panel data which are typically used to assess the short-term impact.

The impact of a minimum wage is not limited to the number of workers who are employed. A minimum wage also impacts on wage distribution, on workers who are earning close to the minimum wage, on number of hours worked, training, and workforce composition. Indeed, employers have a range of potential responses apart from reducing the number of people they employ. A minimum wage might be expected to encourage employers to train their workers and also to create incentives for workers to accumulate human capital in order to avoid unemployment (Askenazy, 2003). ${ }^{5}$ However, Fairris and Pedace (2004) found that minimum wage policies have no effect on the average number of hours of training for those workers who receive it and little evidence that a minimum wage affects the proportion of the workforce

\footnotetext{
${ }^{5}$ Even and Macpherson (2003) argue that this will depend on the mix of low paid workers who are entry level workers who quickly accumulate skills that push their wages above the minimum and those in dead end jobs with no opportunity for advancement.
} 
receiving training. In contrast, Even and Macpherson (2003) suggested that training has a large effect on wage growth of minimum wage workers. They also pointed to other benefits of a minimum wage, such as reducing quit rates, and, as a consequence, the hiring costs of firms. But here again the evidence is mixed, with Grossberg and Sicilian (2004) finding that the impact depends on the ratio of the minimum wage in relation to local market wages. Neumark et al (2004: 449) suggest that "the full range of labor market effects associated with raising the minimum wage most likely reduce the well-being of low-wage workers."

Evidence from the UK on the impact of the NMW is much less equivocal. Using a 'quasi-experimental' approach, similar to that adopted by Card (1992) and Card and Krueger (1994), Stewart (2002) found that employment growth after the introduction of the NMW was not significantly different in areas of the country with a high proportion of low paid workers whose wages increased to comply, from that in areas with a low proportion of such workers. Accordingly, his conclusion was that the introduction of the minimum wage "had no systematic adverse effect on employment" (Stewart, 2002: 603). A subsequent study, analysing the effect of both the introduction of the NMW and its up-ratings, again found no adverse effect on employment (Stewart, 2004). Studies of particular sectors characterised by low pay, such as residential homes (Machin and Wilson, 2001), apparel (Undy et al, 2001), textiles (Heyes and Gray, 2001a), hospitality (Adam-Smith et al, 2003) and hairdressing (Druker et al, 2005), and on specific types of low paid workers, for example, low paid women (Connolly and Gregory, 2002) and Asian home workers in the clothing industry (Heyes and Gray, 2001b) also found no evidence of systematic adverse impacts. Studies investigating the effect of the minimum wage in small businesses 
have reported variable impacts (Ram et al, 2001; Gilman et al 2002; Arrowsmith et al 2003). With regard to the potential wider effects of the NMW, there is no evidence that it had resulted in a reduction in training (Hayes and Grey, 2003; Arulampalam et al, 2004), or wage inequality (Dickens and Manning, 2004). A positive effect on crime rates has also been reported (Hansen and Machin, 2002). However, the NMW has had limited effect in reducing the gender pay gap (Robinson, 2002). The types of workers who have benefited the most from the NMW have been identified by Stewart and Swaffield (2002).

However, this favourable assessment of the impact of the introduction of the NMW needs to be qualified in two significant respects. Firstly, the economic conditions have been favourable: low inflation, low unemployment, economic growth and booming low wage sectors (Brown, 2002). Druker et al (2005: 21) make the following observation based on a study of hairdressers: “...the national minimum wage was introduced at a time when consumers were experiencing a growth in disposable income. Therefore, price increases could be accommodated by customers. Without the general benign economic conditions existing in 1999 and since, the impact may have been rather different." Secondly, we should recall Bazen and Marimoputou's (2002: 723) evidence that "the analysis of long-run time series data gives rise to a different conclusion concerning the employment effects of minimum wages than obtained from short run 'impact' studies." This suggests that any conclusions regarding the impact of the NMW in the UK should be regarded as provisional until the longer-term effects can be more fully examined. 
Conspicuous by its absence from such evaluations is any assessment of the geographical impact of the NMW. Indeed, there have been very few attempts to assess whether any of the new active labour market policies are more effective in some regions than others (Williams, 2001). ${ }^{6}$ It is particularly surprising that this issue is not examined by the Low Pay Commission in its otherwise extremely thorough annual reports on the impact of the minimum wage. These reports acknowledge that the proportion of jobs which pay below minimum wage rates and the percentage of workers whose wages are raised as a result of the introduction or up-rating of a NMW both vary between regions. ${ }^{7}$ In London and the South East, for example, wages rates are typically above the NMW, even among the relatively unskilled. Moreover, there are geographical variations in the cost of living (Wingfield et al, 2005) which affect real wages (money wages deflated by the local cost of living) and these might differ significantly from the geography of nominal money wages. Significant differences in living costs between regions will therefore create variations in the real value of a nationally uniform minimum wage which will be worth less in high cost areas (Sunley and Martin, 2000; 2003). Consequently, the effectiveness of the NMW may vary on account of significant geographical variations not just in the incidence of low pay but also in the cost-of-living (Sunley and Martin, 2000; 2003; Dorling and Thomas, 2004). Furthermore, it is possible that the impact of the NMW will vary depending on the nature of local labour market characteristics such as local wage distribution, local employment and workforce structure and the scale of local unemployment. Gilbert et al (2001) have argued that the NMW will be particularly beneficial for remote rural

\footnotetext{
${ }^{6}$ See Turok and Webster (1998), Sunley et al (2001) and Martin et al (2003) for discussions of the geographical impact of Labour's New Deal.

${ }^{7}$ Indeed, such geographical variations are exploited in economic studies of the impact of the minimum wage by comparing its effect in high wage and low wage areas (Card, 1992; Card and Krueger, 1994; 1995; Stewart, 2002).
} 
areas because of their specific characteristics (e.g. extent of low pay, possibilities for job switching, travel constraints, type of businesses).

Sunley and Martin (2000; 2003), writing at the time that the NMW was introduced, were only able to speculate on its possible geographical impact across the UK. This paper builds on Sunley and Martin's $(2000 ; 2003)$ work by reporting results from a unique dataset comprising responses from over 18,000 small and medium sized enterprises (SMEs) whose owners were questioned on the number of workers affected by the October 2003 up-rating in the value of the NMW and the firm-level mechanisms that they anticipated using in order to cope with cost increases. This paper explores the indirect effects of the introduction and up-rating of the NMW arising from the adjustment mechanisms used by firms. At one extreme, firms could adopt an intensification strategy in which they attempt to recoup the additional costs of a minimum wage, for example, by reducing hours worked and overtime and by substituting adult workers with cheaper young workers. At the other extreme, the imposition of a minimum wage may 'shock' firms into improving their productivity by investing in training, upgrading the skill content of jobs, upgrading products and processes or shifting to producing less price-sensitive products and services. The paper examines whether these alternative types of response are regionally differentiated.

The next section describes the methodology and data source that is used. Section three provides an overview of the impact of the NMW, exploring the proportion of firms and workers that have been affected in different regions and sectors, examines the effect of the NMW up-rate on total wage bills and overall profitability and then goes 
on to explore the range of organisational responses to the NMW up-rate that have taken place within the small firms sector. The concluding section of the paper considers the possible consequences of the NMW on the uneven nature of regional development in the UK.

\section{Methodology and Data Source}

There have been two approaches to studying the impact of the NMW in the UK. The first approach, favoured by labour market economists, is the analysis of large scale surveys of individuals, notably the Labour Force Survey, the New Earnings Survey and the British Household Panel Survey (BHPS). The second approach, often adopted by industrial relations scholars, is a more in-depth qualitative analysis of individual businesses, using small-scale samples, generally drawn from a single industry and located in a single region. This study provides a third approach, the analysis of a large scale survey of small businesses, using the third biennial membership survey of the Federation of Small Businesses (FSB) (Carter et al, 2004), the UK's largest voluntary membership business association. Questionnaires were distributed to all FSB members in October 2003, coinciding with the introduction of an up-rate in the NMW from $£ 4.20$ to $£ 4.50$ per hour for adults and from $£ 3.60$ to $£ 3.80$ per hour for youths (18-21 years old). As noted earlier, this was the first up-rate to raise the NMW by more than the annual average earnings index since its introduction in 1999. In view of its topicality, four questions were included about the impact of the NMW up-rate: (i) how many workers would have their wages increased as a result of the up-rate; (ii) their willingness to employ workers aged 16-17, 18-21 and 22 and over in the future; (iii) whether the up-rate would lead them to increase the pay of higher grade staff in 
order to maintain differentials and (iv) and what firm level changes would be introduced as a result of the NMW up-rate.

Of the 155,000 questionnaires distributed, 18,635 usable responses were received by the mid-November 2003 cut-off date, a response rate of 12.02 per cent. Cost restrictions prevented follow-up mailings to boost response rates, ${ }^{8}$ and data protection restrictions on the mailing list prevented the research team from identifying and contacting non-respondents in order to investigate response bias. Without the option of conventional non-response bias tests, a comparison of early and late responses was used to test response bias. No significant differences between early and late responses were found across any of the five variables typically used to describe the owners and the firms (age of owner, business entry mode, age of business, sales volume and VAT registration). An analysis of respondents, with regard to their sectoral and regional distribution suggested a sample with close similarities to that of UK VAT registered SMEs (SBS, 2003). ${ }^{9}$ Extensive data cleaning was undertaken in order to increase the robustness of the analysis. The main element of this entailed reclassifying respondents' location from regional level to postcode level. While the initial stages of analysis used self-reported regional level data, greater accuracy was required to tease out the geographical impact and effects of the NMW up-rate. Of the 18,635 usable responses, 13,210 were successfully classified using self-reported business postcode

\footnotetext{
${ }^{8}$ However, reminders to complete the questionnaire were included in First Voice, the FSB's monthly magazine which is sent to all members.

${ }^{9}$ While the sample can be compared against known norms established by government funded stratified sample surveys, there is, of course, a broader issue concerning representativenesss of businesses that join membership organisations, for example, in terms of age, size and and the political attitude of their owners. The survey report (Carter et al, 2004) presents further details of the characteristics of respondents. We are, however, unable to comment on the possibility of attitudinal bias. The FSB is a lobby organisation and this might be expected to result in the recruitment of business owners with a strong 'free market' ethos. However, much of the FSB's promotion and certainly its steadily increased membership is based around the wide range of membership benefits that it offers (e.g. help lines, legal advice, low cost products and services) which might be expected to diminish any attitudinal bias.
} 
data. In two neighbouring regions, London and the South East, over-lapping postcodes were dealt with by merging the two regions for the purpose of the analysis. A large number of cases $(5,425)$ contained complete data, but could not be allocated a postcode. These cases were included in the analysis, but remained regionally unallocated. A further 1,568 cases had missing or inconsistent data ${ }^{10}$ and were excluded, leaving 17,067 cases for further analysis.

To date, this is the largest survey to have investigated the effects of the NMW and its up-rates. Indeed, the FSB biennial survey is the largest survey of small businesses in the UK, comfortably exceeding such high profile surveys as the Small Business Service's Annual Small Business Survey (8,000 telephone interviews) (Atkinson and Hurstfield, 2004), the University of Cambridge's Enterprise Challenged report (circa 2000 responses from a survey stratified by size of firm) (Cosh and Hughes, 2003) and the NatWest Quarterly Survey of Small Business in Britain (687 responses in Q4 2003) (Gray, 2003). The number of responses is also substantially greater than that of the LPC's own surveys, which were targeted at sectors most likely to be affected by the NMW. Its most recent survey of a sample of 32,000 companies, for example, achieved, a 10 per cent response rate (Low Pay Commission, 2005). ${ }^{11}$

\section{Survey Evidence}

\footnotetext{
${ }^{10}$ This included 75 cases where the number of up-rated staff exceeded total employment. While many of these cases could be plausibly explained (for example, seasonal workers within the agriculture or the hotels sectors), we took the more cautious approach of excluding these cases from the analysis. Had they been included, the numbers of employees who had been up-rated would have risen from 15,473 to 18,934 .

${ }^{11}$ Moreover, the Low Pay Commission (2005: 5) concedes that respondents "tended to be companies with concerns about the national minimum wage." This is unlikely to be a problem in the case of the FSB survey because of its wide ranging coverage of topics.
} 
The paper seeks to provide answers to four questions concerning the effect of the NMW up-rate on the UK small business sector.

1. What have been the overall effects of the NMW up-rate on the SME sector, and which industries have been most affected?

2. What is the regional impact of the NMW in terms of the proportion of small businesses and employees affected?

3. What have been the consequences of the up-rate on both the wage bill and profitability of small businesses, both nationally and across the regions?

4. What responses do small businesses anticipate taking in order to adjust to the NMW update, and how do these anticipated responses vary regionally?

\subsection{The overall effects of the NMW up-rate on the SME sector}

Small businesses pay lower wages on average than large businesses, and low paying sectors such as clothing manufacture and personal services are dominated by small firms. The Low Pay Commission (2005: 23) note that "the smaller the firm the more likely there will be workers who stand to benefit from the national minimum wage." We would therefore expect that the NMW will have a significant impact in terms of the proportion of SMEs which have to raise wage rates and the proportion of employees whose wages have to be up-rated to the new minimum. However, as Table 2 shows, even after three increases in the value of the NMW since its introduction in 1999, the effect impact of the October 2003 up-rate has been relatively minor and confined to a minority of businesses and employees. First, of those businesses with 
more than one employee ${ }^{12}$, just 21.5 per cent had up-rated any employees. Second, just over 14,000 employees benefited from this statutory rise, which equates to only 9.5 per cent of the total employment $(146,537)$ in these businesses. Finally, of those businesses that did up-rate staff, only a minority of employees were affected, averaging 25 per cent per firm.

\section{TABLE 2 ABOUT HERE}

Table 2 also shows that the impact of the NMW varies by industry sector. Its impact is greatest in the Hotels and Restaurants sector where nearly 42 per cent of businesses have up-rated staff (average of 44 per cent per business) and 20 per cent of employees have benefited from an increase in their wages, more than twice the overall average. The second most affected sector is Personal Services, where 32 per cent of businesses and 15 per cent of employees were affected (average of 37 per cent of employees per business). This is followed by a cluster of service industries: Retail, Wholesale and Motor Trades, Education, and Health and Social Work, where over one-quarter of businesses and between 10 and 14 per cent of employment has been affected.

Industries that have been least affected by the NMW up-rate are Energy and Water, Financial Services, Business Services and Construction. The proportion of Manufacturing businesses that have been affected, and the proportion of employees up-rated are also below the national average.

\footnotetext{
${ }^{12}$ The questionnaire asked business owners to include themselves and any partners in their reported employment figures. Thus, a business which reports one employee has no additional employees and some businesses reporting more than one employee will consist of multiple owners or partners. Since owners/partners are not subject to the NMW, the inclusion of such businesses inflates the denominator and reduces the proportion of businesses that have up-rated employees to the new NMW rate. However, given the known employment characteristics of the small firms sector, this effect is likely to be marginal.
} 


\subsection{The regional impact of the NMW up-rate}

Turning to the geographical impact, there is clear north-south contrast at the regional scale, with the proportion of businesses (with more than one employee) that have uprated employees ranging from 14.7 per cent in London and the South East to over one-quarter in the North East, North West, Wales, Scotland and Northern Ireland (Table 3). The proportion of employees up-rated ranges from a low of 5.8 per cent in London and the South East to a high of over 17.5 per cent in Wales. In those businesses which up-rated employees, the average proportion of employees up-rated per business ranges from 19 per cent in London and the South East to more than onethird in the North East, Wales, Scotland and Northern Ireland. This pattern is very much in line with regional variations in household income (Regional Trends, 2004), with the limited impact of the NMW in London and the South East consistent with the region's much higher average earnings (Buck et al, 2002) and low proportion of low paid workers (Dorling and Thomas, 2004). Moreover, these differences in the regional effect of the NMW up-rate are independent of industry composition, with regional effects in evidence for individual industries.

\section{TABLE 3 ABOUT HERE}

There is also an urban-rural dimension to the NMW up-rate. ${ }^{13}$ Mapping the geography of low pay suggests that most of the country's major conurbations have lower proportions of workers earning minimum wages than rural areas (Sunley and Martin,

\footnotetext{
${ }^{13}$ The urban-rural classification was derived from post-codes that were matched to those provided in the Manchester Census Data Centre and the enumeration districts were obtained. From these, two different urban-rural classifications were available: one for England and Wales and another for Scotland. These were made to correspond by reducing the number of categories to a binary urban-rural distinction. While this was a robust procedure, a sizeable minority of respondents could not be classified by this process and have been omitted from the urban-rural analysis.
} 
2003). This leads to the expectation that the NMW up-rate will be greater in rural areas. However, this is contrary to the evidence gathered from the survey (Table 4) which indicates that the proportion of businesses up-rating employees, the proportion of employees who are up-rated and the average proportion of workers up-rated in those businesses that up-rated any staff are all higher in urban areas. Here again, this conclusion is independent of industry effects. This discrepancy may be at least partly explained by the growing polarity in income distributions in major conurbations, and London in particular (Buck et al, 2002), with high earners concentrated in larger businesses. In addition, wage rates are not uniformly low in rural areas but tend to be concentrated in those labour markets dominated by agriculture, retail and tourism (Sunley and Martin, 2003).

\section{TABLE 4 ABOUT HERE}

\subsection{The impact of the NMW up-rate on the wage bills and profitability of SMEs}

Firms that had up-rated one or more employees were asked to indicate the consequence for their wage bill and profitability using a five point Likert type scale ( $1=$ significant decrease $5=$ significant increase). The majority of businesses that had up-rated employees, around 70 per cent, anticipated that their wage bill would be unaffected as a result of the NMW up-rate, with 23 per cent expecting a slight increase and just 4 per cent per cent expecting a significant increase. The mean response for the total wage bill item was 3.28 , indicating an overall expectation that total wage bills would increase slightly. This is consistent with our earlier evidence that in most cases where businesses were up-rating employees, only a minority of employees were affected. It also confirms and reinforces the findings of small-scale 
qualitative industry and regional studies that report a limited impact on wage bills (e.g. Sehkaran, 2001; Druker et al, 2005).

In terms of regional effects, and considering only those businesses that had up-rated one or more employees, London and the South East had the smallest proportion of businesses that expected their wage bill to rise ( 20 per cent). This contrasts with several of the regions in the 'north', where over 30 per cent of businesses affected by the NMW up-rate expected it to lead to an increase in their wage bill (Table 5). Post hoc tests indicate that London and the South East businesses are significantly less likely to anticipate raising their wage bill than all other regions expect the West Midlands and East of England, while Wales has significantly more businesses than London and then South East which expect the NMW up-rate to result in an increase in their wage bill.

\section{TABLE 5 ABOUT HERE}

The impact on profitability is also relatively modest. Just over 20 per cent of businesses that up-rated any employees expected this to result in a decrease in their profitability. The mean response for overall profitability was 2.84 , indicating an expectation amongst firms affected by the NMW up-rate that it would result in a modest decrease in their profitability (Table 5). Here again, this confirms the conclusions of smaller-scale in-depth studies (e.g. Edwards et al, 2004; Arrowsmith et al, 2003; Heyes and Gray, 2004). 
Not surprisingly, given the earlier evidence on the effect of the NMW up-rate on wage bills, London and the South East contained the smallest proportion of businesses that anticipated a decline in profitability, at just 15 per cent. In contrast, around onequarter of businesses in the North East, Northern Ireland, Wales, Yorkshire and The Humber and the North West anticipated a decrease in their profitability as a result of the NMW up-rate. Turning to urban-rural contrasts, there were no statistically significant differences in either the proportions of firms anticipating increases in wage bills or reductions in their profitability as a result of the NMW up-rate.

\subsection{Anticipated adjustment responses}

Twelve potential responses to the NMW increase, covering direct employment effects, cost measures and quality enhancement, based on a prior study by Heyes and Gray (2003), were included in this study. Each was measured using a five point Likert type scale ranging from significant decrease (1) to significant increase (5).

The main anticipated response to the NMW uprate is to increased prices (mean $=$ 3.22). However, as many SMEs operate in highly competitive markets this is not an option in the majority of cases (Grimshaw and Carroll, 2002). In terms of employment, businesses anticipated that the NMW uprate would result in a modest decline in the number of employees (mean $=2.94)$. A separate analysis for type of worker by age indicated that such reductions would be marginally greater amongst 16-17 year olds and adult workers than amongst 18-21 year olds. In fact, reductions in basic hours $($ mean $=2.90)$ and overtime $($ mean $=2.94)$ are more likely ways in which labour inputs will be reduced, although here again the likely effect of such actions appears likely to be modest. The NMW uprate is unlikely to prompt 
significant changes in methods of remuneration such as incentive payments $($ mean $=$ $2.94)$ and non-wage benefits $($ mean $=2.96)$, control of labour costs $($ mean $=2.99)$ or training $($ mean $=2.99)$. Neither is there any evidence that the NMW up-rate will prompt significant numbers of SMEs into 'virtuous' responses such as investing in new capital equipment or enhancing the quality of products/services (means of 3.01 and 3.06 respectively).

\section{TABLE 6 ABOUT HERE}

There are differences in how businesses have responded to the NMW up-rate in different regions (Table 6). However, statistically significant regional differences in responses were confined to three items. First, businesses in London and the South East were significantly less likely to anticipate raising prices compared with those in Yorkshire and The Humber, South West, North West, Wales, Scotland and Northern Ireland $(F=5.137, p<0.000)$. Second, businesses in the North East were most likely to respond by reducing non-wage benefits, whereas those businesses in London and the South East, South West, North West and Scotland were least likely to do so $(\mathrm{F}=2.823, \mathrm{p}<0.001)$. Third, businesses in London and the South East were least likely to consider controlling non-wage costs whereas those in the South West were most likely to do so $(\mathrm{F}=3.117, \mathrm{p}<.0 .000)$. There were no significant urban-rural differences in the types of anticipated responses made by businesses affected by the NMW.

\section{Conclusion}

This paper offers a unique perspective on the impact of the National Minimum Wage. First, it is based on a very large-scale survey of SMEs whereas most studies have 
either been based on official labour force or earnings survey data or on small-scale samples of businesses. Second, it is the largest survey of businesses to have investigated the impact of the NMW. Third, it is the first paper to present data on the regional impact of the NMW.

The evidence in this paper suggests that the NMW up-rate in October 2003 had a relatively minor effect on UK small businesses because most of their employees were already being paid above the national minimum rate. Overall, only 10 per cent of employees benefited from a wage up-rate, just over 21 per cent of businesses up-rated employees and only a minority of employees in these businesses (average of 25 per cent) were up-rated. The impact has varied across industries, with the Hotels and Restaurants sector experiencing the greatest effect. The Retailing, Personal Services, Education, and Health and Social Work industries have also been disproportionately affected. The anticipated effect of the NMW up-rate on the total wage bill and profitability of businesses are also likely to be relatively limited. In most cases businesses expect to be able to absorb the cost or have no alternative but to do so. Some businesses plan to raise prices but this is not a feasible option for many SMEs. The main impact - but still confined to a minority of businesses - is likely to be a modest decrease in employment of both youths and adults. Contrary to the expectations (or hopes?) of some commentators, there is no evidence that the NMW will have a 'shock effect' on SMEs, with very few planning to adopt high level competitive strategies based around capital investment and improved service and product quality. In short, this study provides authoritative confirmation of the findings of previous smaller scale qualitative business surveys that the NMW has had limited effect on the small business sector, contrary to the fears expressed by some parts of 
the business community prior to its launch. It is truly an example of a dog which did not bark, at least so far.

The main contribution of this paper has been the analysis of the regional impact of the NMW, an issue that has been largely ignored in previous research. The evidence presented here has highlighted significant regional variations in the NMW's 'bite', in terms of the proportion of businesses raising the wages of their employees and the proportion of employees whose wages are raised. Limited impact in London and the South East, where most SMEs are already paying above minimum wages can be contrasted with the effect of the NMW in 'the north' - notably the North East, North West, Wales and Scotland. However, it is important to recognise the interrelationships between wage rates, cost-of-living and social payments which create "spatial variations in the extent to which work pays" (Williams, 2001: 210). Flat-rate welfare payments and higher cost of living means that work pays to a greater extent in the south than the north, so a minimum wage has less of an incentive effect. On the other hand, the higher cost of living in London and the South East means that the real wages of those in employment may be as low, if not lower, than those living elsewhere (Williams, 2001). This provides one reason for suggesting that the case for a regionally differentiated minimum wage is given serious consideration.

Turning to the effect on the NMW on SMEs, among businesses that have up-rated the pay of their employees, those in London and South East are least likely to anticipate an increase in their wage bill. Businesses have responded in various ways to the NMW up-rate, with the clearest regional effect being for businesses in the 'north' plan price increases compared with those in London and the South East. This is consistent 
with evidence that SMEs in London and the South East are more profitable, on average, than firms in other parts of the UK (Keeble, 1997), making it easier for them to absorb increases in their wage bill resulting from the raising of the minimum wage. Studies using data from the University of Cambridge surveys of British Business (Keeble and Bryson, 1996; Keeble, 1997; 2003) have noted that SMEs in northern regions, particularly in the service sector, place greater emphasis on price and cost advantages as their most important competitive strengths than firms in both the Industrial Heartland regions and South East (including Greater London). This leads Keeble (1997: 290) to suggest that "there may be systematic differences in the regional competitive environment confronting SMEs ... business success in the more open and competitive South East being more dependent on specialisation, niche marketing and attention to product design, whereas Peripheral firms try to compete by the more traditional small firm method of offering a rapid service and, in the service sector, on lower price and cost advantages." The implication is that by forcing SMEs in the north to raise their prices, the NMW is having a differentially adverse effect on their competitiveness. SMEs in 'the north' may also be put at a relative disadvantage by the trend for the public sector to significantly raise their national minimum wages (Income Data Services, 2001). This is on account of both their greater reliance on semi-skilled and unskilled workers (Keeble and Bryson, 1996) and also the difference between a nationally set wage and the 'going rate' in different regions which takes into account demand and supply considerations and the cost-of-living.

The evidence presented here that demonstrates that the impact of the NMW varies between regions, and that the response of SMEs to the NMW also varies regionally, prompts two final observations. First, previous analyses of the NMW based on a 
single region (e.g. Grimshaw and Carroll, 2002; Heyes and Grey, 2004) cannot be assumed to apply to other geographical regions and contexts. Second, future evaluations by the Low Pay Commission of the impact of the minimum wage must incorporate a thorough analysis of its geographical outcomes.

Acknowledgement. This paper is based on data collected by the authors on behalf of the Federation of Small Businesses' biennial membership survey undertaken in October 2003 and published in April 2004 (Carter et al, 2004). The views expressed here are solely those of the authors.

\section{References}

Adam-Smith, D., Norris, G. and Williams, S. (2003). Continuity or Change? The Implications of the National Minimum Wage for Work and Employment in the Hospitality Industry. Work, Employment and Society 17(1): 29-47.

Arrowsmith, J. Gilman, M., Edwards, P. and Ram, M. (2003). The Impact of the National Minimum Wage in Small Firms. British Journal of Industrial Relations 41(3): 435-456.

Arulampalam, W., Booth, A. and Bryan, M. (2004). Training and the New Minimum Wage. The Economic Journal 114: C87-C94.

Askenazy, P. (2003). Minimum Wage, Exports and Growth. European Economic Review 47:147-164.

Atkinson, J. and Hurstfield, J. (2004). Annual Small Business Survey 2003 London: Small Business Service.

Bazen, S. and Marimoutou, V. (2002). Looking for a Needle in a Haystack? A Reexamination of the Time Series Relationship Between teenage Employment and Minimum Wages in the United States. Oxford Bulletin of Economics and Statistics 64: 699-725.

Brown, W. (2002). The Operation of the Low Pay Commission. Employee Relations 24(6): 595-605.

Buck, N, Gordon, I, Hall, P, Harloe, M and Kleinman, M (2002) Working Capital: Life and Labour in Contemporary London, Routledge: London.

Card, D. (1992). Using Regional Variation in Wages to Measure the Effects of the Federal Minimum Wage. Industrial and Labor Relations Review 46(1): 22-37. 
Card, D. and Krueger, A. (1994). Minimum Wages and Employment: A Case Study of the Fast Food Industry in New Jersey and Pennsylvania. The American Economic Review 84(4): 772-793.

Card, D. and Krueger, A. (1995). Myth and Measurement: The New Economics of the Minimum Wage Princeton, N.J.: Princeton University Press.

Carter, S. Mason, C. and Tagg, S. (2004). Lifting the Barriers to Growth in UK Small Businesses: The FSB Biennial Membership Survey, 2004 London: Federation of Small Businesses.

Connolly, S. and Gregory, M. (2002). The National Minimum Wage and Hours of Work: Implications for Low Paid Women. Oxford Bulletin of Economics and Statistics 64:607-631.

Cosh, A. and Hughes, A. (2003). Enterprise Challenged: Policy and Performance in the British SME Sector 1999-2002. Cambridge: University of Cambridge Centre for Business Research.

Deere, D. Murphy, K. and Welch, F. (1995). Re-examining Methods of Estimating Minimum Wage Effects: Employment and the 1990-1991 Minimum Wage Hike. The American Economic Review 85(2): 232-237.

Dickens, R, Gregg, P and Wadsworth, J (2000) New Labour and the labour market, Oxford Review of Economic Policy, 16 (1): 95-113.

Dickens, R. and Manning, A. (2004). Spikes and Spill-overs: The Impact of the National Minimum Wage on the Wage Distribution in a Low-Wage Sector. The Economic Journal 114: C95-C101.

Dorling, D and Thomas, B (2004) People and Places: A 2001 Census Atlas of the UK, Bristol: Polity Press.

Druker, J., White, G and Stanworth, C. (2005) Coping with wage regulation: implementing the National Minimum wage in hairdressing businesses. International Small Business Journal, 23, 5-25.

Even, W. and Macpherson, D. (2003). The Wage and Employment Dynamics of Minimum Wage Workers. Southern Economic Journal 69(3): 676-690.

Farris, D. and Pedace, R. (2004). The Impact of Minimum Wages on Job Training: An Empirical Exploration with Establishment Data. Southern Economic Journal 70(3): 566-583.

Fergusson, R (2002) Rethinking youth transitions: policy transfer and new exclusions in New Labour's New Deal, Policy Studies, 23 (3/4): 173-190.

Financial Times (2004) Minimum wage extended to stop exploitation of younger workers, 16 March, 3. 
Financial Times (2005a) Fears about job destruction proved to be unfounded, 30 September, 6.

Financial Times (2005b) Taking risks with the job market, 28 February, 20

Gilbert, A., Phimister, E. and Theodossiou, I. (2001). The Potential Impact of the Minimum Wage in Rural Areas. Regional Studies 35(8): 765-70.

Gilman, M. Edwards, P, Ram, M. and Arrowsmith, J. (2002). Pay Determination in Small Firms in the UK: The Case of the response to the National Minimum Wage. Industrial Relations Journal 33(1) : 52-67.

Gray, C. (2003). Natwest Quarterly Survey of Small Business in Britain 2003 Q4. Milton Keynes: Open University Business School.

Grimshaw, D and Carroll, M (2002) Qualitative Research on Firms'Adjustments to the Minimum Wage, European Work and Employment Research Centre, Manchester School of Management, UMIST

Grossberg, A. and Sicilian, P. (2004). Legal Minimum Wages and Employment Duration. Southern Economic Journal 70(3): 631-645.

Hansen. K. and Machin, S. (2002). Spatial Crime Patterns and the Introduction of the UK Minimum Wage. Oxford Bulletin of Economics and Statistics 64: 677-697.

Haughton, G., Jones, M., Peck, J., Tickell, A. and While, A. (2000). Labour Market Policy as Flexible Welfare: Prototype Employment Zones and the New Workfarism. Regional Studies 34(7): 669-680.

Heyes, J. and Gray, A. (2001a). The Impact of the National Minimum Wage on the Textiles and Clothing Industry. Policy Studies 22(2): 83-98.

Heyes, J. and Gray, A. (2001b). Homeworkers and the National Minimum Wage: Evidence from the Textiles and Clothing Industry. Work, Employment and Society 15(4): 863-873.

Heyes, J. and Gray, A. (2003). The Implications of the National Minimum Wage for Training in Small Firms. Human Resources Management Journal 13(2): 76-86.

Hayes, J and Gray, A (2004) Small firms and the National Minimum Wage: implications for pay and training practices in the British private service sector, Policy Studies, 25 (3): 209-225.

Income Data Services (2001) Public sector driving up lowest grade rates, IDS Pay Report 835 .

Keeble (1997) Small firms, innovation and regional development in Britain in the 1990s, Regional Studies, 31 (3): 281-293. 
Keeble, D (2003) British SMEs in the $21^{\text {st }}$ century: north-south and urban-rural variations in performance and growth, in A Cosh and A Hughes (eds) Enterprise Challenged: Policy and Performance in the British SME Sector 1999-2002.

Cambridge: University of Cambridge Centre for Business Research, pp 87-102.

Keeble, D and Bryson, J (1996) Small-firm creation and growth, regional development and the North-South divide in Britain, Environment and Planning A, 28, 909-934.

Levin-Waldman, O. (2002). The Minimum Wage and Regional Wage Structure: Implications for Income Distribution. Journal of Economic Issues 36(3): 635-657.

Low Pay Commission (2001) The National Minimum Wage. Making a Difference: The Next Steps - Third Report of the Low Pay Commission, London, TSO, Cm 5175

Low Pay Commission (2003). The National Minimum Wage: Fourth Report of the Low Pay Commission. Building on Success. London: TSO.

Low Pay Commission (2005). The National Minimum Wage: Low Pay Commission Report 2005. London: TSO. Cm 6475.

Machin, S. and Wilson, J. (2001). Minimum Wages in a Low-Wage Labour Market: Care Homes in the UK. The Economic Journal 114:C102-C109.

Martin, R. (2000). Local Labour Markets: their Nature, Performance and Regulation. In G. Clark, M. Gertler and M. Feldman (eds). Handbook of Economic Geography Oxford: Oxford University Press.

Martin, R. and Morrison, P. (2003). The Geographies of Labour Market inequality: Some Emergent Issues and Challenges. In R. Martin and P. Morrison (eds.) Geographies of Labour Market Inequality. London: Routledge, pp. 241-264.

Martin, R., Nativel, C. and Sunley, P. (2003). The Local Impact of the New Deal: Does Geography Make a Difference? In R. Martin and P. Morrison (eds.) Geographies of Labour Market Inequality. London: Routledge, pp. 175-207.

Metcalf, D. (1999). The Low Pay Commission and the National Minimum Wage. The Economic Journal 109:F46-F66.

Metcalf, D. (2002). The National Minimum Wage: Coverage, Impact and Future. Oxford Bulletin of Economics and Statistics 64: 567-582.

Metcalf, D. (2004). The Impact of the National Minimum Wage on the Pay Distribution, Employment and Training The Economic Journal 114:C84-86.

Neumark, D. Schweitzer, M. and Wascher, W. (2004). Minimum Wage Effects Throughout the Wage Distribution. The Journal of Human Resources 39(2): 425-449. 
Office for National Statistics (2003) Commerce, Energy \& Industry: Size Analysis of UK Businesses, PA 1003, Data for 2003, London: Office for National Statistics.

Peck, J. and Theodore, N. (2000). 'Work First': Workfare and the regulation of Contingent Labour Markets. Cambridge Journal of Economics 24(1): 119-138.

Pereira, S. (2001). The Impact of Minimum Wages on Youth Employment in Portugal. European Economic Review 47: 229-244.

Ram, M. Edwards, P. and Gilman, M. (2001). The Dynamics of Informality: Employment Relations in Small Firms and the effects of regulatory Change. Work, Employment and Society 15(4): 845-861.

Robinson, P (2000) Active labour-market policies: a case of evidence-based policymaking? Oxford Review of Economic Policy, 16 (1): 13-26.

Robinson, H. (2002). Wrong Side of the Track? The Impact of the Minimum Wage on gender pay Gaps in Britain. Oxford Bulletin of Economic Statistics 64(5): 417-448.

Sachdev, S. (2003). Raising the Rate: An Evaluation of the Uprating Mechanism for the Minimum Wage. Employee Relations 25(4):405-415.

Sehkaran, S N (2001) The National Minimum Wage and Young Workers: Implications for Employment and Training in Urban and Rural Areas, Manchester Metropolitan University Business School Working Paper 01/12.

Small Business Service (2003) Business Start-Ups and Closures: VAT Registrations and Deregistrations in 2002, Press Release issued $21^{\text {st }}$ October 2003, London: Small Business Service.

Stewart, M. (2002). Estimating the Impact of the Minimum Wage Using Geographical Wage Variation. Oxford Bulletin of Economics and Statistics 64: 583-605.

Stewart, M. (2004). The Employment effects of the National Minimum Wage. The Economic Journal 114: C110-C116.

Stewart, M. and Swaffield, J. (2002). Using the BHPS Wave 9 Additional Questions to Evaluate the Impact of the National Minimum Wage. Oxford Bulletin of Economics and Statistics 64: 633-652.

Sunley, P. Martin, R. and Nativel, C. (2001). Mapping the New Deal: Local Disparities in the Performance of Welfare-to-Work. Transactions of the Institute of British Geographers 26(4): 484-512.

Sunley, P. and Martin, R. (2000). The Geographies of the National Minimum Wage. Environment and Planning A 32(10): 1735-1758.

Sunley, P. and Martin, R. (2003). The Geographies of a National Minimum Wage. In R. Martin and P. Morrison (eds.) Geographies of Labour Market Inequality. London: Routledge, pp. 208-238. 
Sutherland, H (2001) The National Minimum Wage and In-Work Poverty, University of Cambridge, Department of Applied Economics, Microsimulation Unit Discussion Paper MU0102.

Turok, I and Webster, D (1998) The New Deal: jeopardised by the geography of unemployment? Local Economy, 12: 309-328.

Undy, R., Kessler, I. And Thompson, M. (2001). The Impact of the National Minimum Wage on the Apparel Industry. Industrial Relations Journal.33 (4) : 351364.

Williams, C C (2001) Does work pay? Spatial variations in the benefits of employed and coping abilities of the unemployed, Geoforum, 32, 199-214.

Wingfield, D, Fenwick, D and Smith K (2005) Relative regional consumer price levels in 2004, Economic Trends, 615, 36-45 
Table 1. The changing value of the UK's National Minimum Wage

\begin{tabular}{|l|c|c|c|}
\hline $\begin{array}{l}\text { Date } \\
\text { (Oct) }\end{array}$ & $\begin{array}{c}\text { Adult Hourly Rate } \\
\text { (over 22) }\end{array}$ & $\begin{array}{c}\text { Development Rate for } \\
\text { Young Workers (18-21) }\end{array}$ & $\begin{array}{c}\text { Rate for 16-17 year } \\
\text { olds }\end{array}$ \\
\hline 1999 & 3.60 & 3.00 & - \\
\hline 2000 & 3.70 & 3.20 & - \\
\hline 2001 & 4.10 & 3.50 & - \\
\hline 2002 & 4.20 & 3.60 & - \\
\hline 2003 & 4.50 & 3.80 & 3.00 \\
\hline 2004 & 4.85 & 4.10 & 3.00 \\
\hline 2005 & 5.05 & 4.25 & To be reviewed \\
\hline 2006 & $5.35^{*}$ & $4.95^{*}$ & \\
\hline
\end{tabular}

Note:

* Provisional, subject to further advice from the Low Pay Commission in early 2006. 
Table 2. The impact of the National Minimum Wage up-rate by industry

\begin{tabular}{|c|c|c|c|c|c|c|c|}
\hline Industry & $\begin{array}{r}\text { Total No. } \\
\text { businesses } \\
\end{array}$ & $\begin{array}{r}\text { No. businesses up- } \\
\text { rating }\end{array}$ & $\begin{array}{r}\% \\
\text { businesses } \\
\text { uprating } \\
\end{array}$ & $\begin{array}{r}\text { Total No. } \\
\text { employees }\end{array}$ & $\begin{array}{r}\text { Total no. up- } \\
\text { rated on } \\
\text { NMW }\end{array}$ & $\begin{array}{r}\% \\
\text { employees } \\
\text { uprated } \\
\end{array}$ & $\begin{array}{r}\text { Average \% } \\
\text { employees } \\
\text { uprated } \\
\text { per firm } \\
\end{array}$ \\
\hline Agriculture Forestry \& Fishing & 509 & 84 & 16.5 & 4406 & 327 & 7.4 & 27.1 \\
\hline Mining \& Quarrying & 42 & 8 & 19.0 & 549 & 21 & 3.8 & 18.5 \\
\hline Manufacturing & 1731 & 324 & 18.7 & 21097 & 1350 & 6.4 & 17.2 \\
\hline Energy \& Water & 93 & 8 & 8.6 & 860 & 14 & 1.6 & 10.2 \\
\hline Construction & 1486 & 199 & 13.3 & 15961 & 515 & 3.2 & 15.8 \\
\hline Retail, Wholesale \& Motor Trade & 3342 & 1025 & 30.6 & 26455 & 3728 & 14.0 & 36.4 \\
\hline Hotels \& Restaurants & 1117 & 469 & 41.9 & 13776 & 2782 & 20.1 & 44.4 \\
\hline Transport \& Communications & 623 & 124 & 19.9 & 8366 & 522 & 6.2 & 22.8 \\
\hline Financial Services & 452 & 51 & 11.2 & 2699 & 94 & 3.4 & 15.3 \\
\hline Business Services & 2138 & 230 & 10.7 & 18866 & 1054 & 5.5 & 13.3 \\
\hline Public Administration \& Defence & 15 & 0 & 0 & 754 & 0 & 0.0 & 0.0 \\
\hline Education & 213 & 63 & 29.5 & 3090 & 319 & 10.3 & 22.4 \\
\hline Health \& Social Work & 341 & 91 & 26.6 & 8163 & 1023 & 12.5 & 36.6 \\
\hline Personal Services & 214 & 69 & 32.2 & 2524 & 382 & 15.1 & 37.8 \\
\hline Other & 2136 & 374 & 17.5 & 18971 & 1928 & 10.1 & 24.0 \\
\hline Total & 14452 & 3119 & 21.5 & 146537 & 14059 & 9.5 & 24.4 \\
\hline
\end{tabular}

Notes: Only businesses with more than one employee included in Table 2. The totals in Tables 2,3 and 4 differ as a consequence of missing data. $X^{2} 752.49$ Asymp.Sig (2-sided) 0.00, df $=14, p<.001 F(14,5639)=46.958 p<.001$ 
Table 3. The impact of the National Minimum Wage up-rate by region

\begin{tabular}{|c|c|c|c|c|c|c|c|}
\hline $\begin{array}{l}\text { Region (based on post } \\
\text { code) }\end{array}$ & $\begin{array}{r}\text { Total } \\
\text { no.of } \\
\text { businesses }\end{array}$ & $\begin{array}{r}\text { No. of } \\
\text { businesses } \\
\text { up-rating }\end{array}$ & $\begin{array}{r}\% \\
\text { businesses } \\
\text { uprating } \\
\end{array}$ & $\begin{array}{r}\text { Total } \\
\text { no. } \\
\text { employees }\end{array}$ & $\begin{array}{c}\text { Total } \\
\text { no. up-rated } \\
\text { on NMW }\end{array}$ & $\begin{array}{r}\% \\
\text { employees } \\
\text { uprated } \\
\end{array}$ & $\begin{array}{r}\text { Average } \\
\% \\
\text { employees } \\
\text { uprated } \\
\text { per firm } \\
\end{array}$ \\
\hline Insufficient Postcode & 4544 & 881 & 19.3 & 44360 & 3776 & 8.5 & 25.2 \\
\hline North East & 372 & 110 & 29.5 & 3547 & 490 & 13.8 & 35.7 \\
\hline Yorkshire \& Humberside & 709 & 175 & 24.6 & 7479 & 1078 & 14.4 & 30.0 \\
\hline East Midlands & 931 & 224 & 24.0 & 10615 & 878 & 8.2 & 25.7 \\
\hline East England & 451 & 104 & 23.0 & 5268 & 539 & 10.2 & 25.2 \\
\hline London \& South East & 2496 & 368 & 14.7 & 24933 & 1462 & 5.8 & 19.6 \\
\hline South West & 1652 & 358 & 21.6 & 14444 & 1300 & 9.0 & 26.1 \\
\hline West Midlands & 688 & 139 & 20.2 & 8064 & 588 & 7.2 & 23.9 \\
\hline North West & 773 & 219 & 28.3 & 9519 & 1242 & 13.0 & 31.4 \\
\hline Wales & 494 & 154 & 31.1 & 4679 & 822 & 17.5 & 35.4 \\
\hline Scotland & 1136 & 298 & 26.2 & 10654 & 1418 & 13.3 & 33.9 \\
\hline Northern Ireland & 318 & 111 & 34.9 & 4175 & 566 & 13.5 & 37.1 \\
\hline TOTAL & 14564 & 3141 & 21.5 & 147737 & 14159 & 9.5 & 26.5 \\
\hline
\end{tabular}

Notes: Only businesses with more than one employee included in Table 3. The totals in Tables 2, 3 and 4 differ as a consequence of missing data. $X^{2} 200.32 \mathrm{p}<.001 \mathrm{~F}(11,5675)=11.645 \mathrm{p}<.001$ 
Table 4. Urban - rural differences in National Minimum Wage up-rating

\begin{tabular}{|l|r|r|r|l|}
\hline & Rural & Urban & Total & Sig. \\
\hline No. of businesses & 2282 & 9243 & 11525 & \\
\hline No. businesses $>1$ employee & 1922 & 7994 & 9916 & \\
\hline No. businesses $>1$ up-rated & 384 & 1834 & 2218 & \\
\hline \% businesses $>1$ up-rated & 19.98 & 22.94 & 22.37 & $X^{2} 21.056 \mathrm{df}=1, \mathrm{p}<.001$ \\
\hline Total employees & 19794 & 82248 & 102042 & \\
\hline Total employees up-rated & 1562 & 8536 & 10098 & \\
\hline \% employees up-rated & 7.89 & 10.38 & 9.90 & \\
\hline Mean \% employees up-rated & 25.32 & 27.79 & 27.33 & $\mathrm{~F}(1,3945)=3.217 \mathrm{NS}$ \\
\hline
\end{tabular}

The totals in Tables 2,3 and 4 differ as a consequence of missing data. 
Table 5. The anticipated effect of the national minimum wage up-rate on employment costs and profitability by region

\begin{tabular}{|c|c|c|c|c|c|c|c|c|c|c|c|c|}
\hline & \multicolumn{6}{|c|}{ Total wage bill } & \multicolumn{6}{|c|}{ Overall profitability } \\
\hline $\begin{array}{l}\text { Region } \\
\text { (based on postcode }\end{array}$ & $\begin{array}{l}\% \text { sign } \\
\text { decrease }\end{array}$ & $\begin{array}{l}\text { \% slight } \\
\text { decrease }\end{array}$ & $\begin{array}{l}\% \text { no } \\
\text { change }\end{array}$ & $\begin{array}{l}\% \text { slight } \\
\text { increase }\end{array}$ & $\begin{array}{l}\text { \% sign } \\
\text { increase }\end{array}$ & mean & $\begin{array}{l}\text { \% sign } \\
\text { decreas } \\
\text { e }\end{array}$ & $\begin{array}{l}\text { \% slight } \\
\text { decreas } \\
\text { e }\end{array}$ & $\begin{array}{l}\% \text { no } \\
\text { change }\end{array}$ & $\begin{array}{l}\% \text { slight } \\
\text { increase }\end{array}$ & $\begin{array}{l}\text { \% sign } \\
\text { increase }\end{array}$ & mean \\
\hline Insufficient Postcode & 0.8 & 2.4 & 70.9 & 21.6 & 4.2 & 3.26 & 3.6 & 17.4 & 72.5 & 5.5 & 1.0 & 2.83 \\
\hline North East & 2.2 & 2.5 & 59.7 & 31.3 & 4.4 & 3.33 & 3.7 & 23.7 & 66.0 & 5.9 & 0.6 & 2.76 \\
\hline $\begin{array}{l}\text { Yorkshire \& } \\
\text { Humberside }\end{array}$ & 0.7 & 1.8 & 65.4 & 26.4 & 5.7 & 3.35 & 3.4 & 20.8 & 70.2 & 4.9 & 0.7 & 2.79 \\
\hline East Midlands & 0.9 & 2.0 & 67.1 & 25.9 & 4.1 & 3.30 & 3.3 & 19.9 & 69.9 & 5.5 & 1.3 & 2.81 \\
\hline East England & 0.5 & 3.1 & 67.6 & 25.4 & 3.4 & 3.28 & 2.6 & 19.8 & 69.8 & 6.2 & 1.5 & 2.84 \\
\hline London \& South East & 0.4 & 1.7 & 77.6 & 18.1 & 2.1 & 3.20 & 2.1 & 13.0 & 78.6 & 5.7 & 0.7 & 2.90 \\
\hline South West & 0.5 & 2.1 & 68.8 & 24.4 & 4.2 & 3.30 & 2.7 & 16.9 & 72.6 & 6.8 & 1.0 & 2.87 \\
\hline West Midlands & 0.7 & 1.8 & 71.6 & 21.8 & 4.0 & 3.27 & 4.2 & 15.5 & 72.8 & 7.1 & 0.3 & 2.84 \\
\hline North West & 1.3 & 2.5 & 64.3 & 25.0 & 6.8 & 3.33 & 4.1 & 19.8 & 67.3 & 7.5 & 1.2 & 2.82 \\
\hline Wales & 0.5 & 3.3 & 60.7 & 28.7 & 6.8 & 3.38 & 3.7 & 21.5 & 67.9 & 5.6 & 1.2 & 2.79 \\
\hline Scotland & 0.7 & 1.7 & 66.9 & 27.0 & 3.6 & 3.31 & 3.6 & 18.3 & 69.8 & 7.7 & 0.5 & 2.83 \\
\hline Northern Ireland & 0.7 & 3.9 & 59.3 & 28.2 & 7.9 & 3.39 & 1.8 & 24.3 & 63.8 & 8.7 & 1.4 & 2.84 \\
\hline Total & 0.7 & 2.2 & 69.7 & 23.2 & $4.1 *$ & 3.28 & 3.2 & 17.6 & 72.2 & 6.1 & 0.9 & $2.84 * *$ \\
\hline
\end{tabular}

$* \mathrm{~F}(11,12272)=7.645 \mathrm{p}<.001 * * \mathrm{~F}(11,12257)=3.526 \mathrm{p}<.001$ 
Table 6. Anticipated responses of businesses to the NMW uprate

\begin{tabular}{|c|c|c|c|c|c|c|c|c|c|c|c|c|}
\hline & $\begin{array}{l}\text { No. of } \\
\text { People } \\
\text { Empl'd }\end{array}$ & $\begin{array}{l}\text { Basic } \\
\text { hours } \\
\text { worked }\end{array}$ & $\begin{array}{l}\text { Overtime } \\
\text { hours }\end{array}$ & $\begin{array}{l}\text { Incentive } \\
\text { payments } \\
\text { (bonuses, } \\
\text { tips, etc) }\end{array}$ & $\begin{array}{l}\text { Non-wage } \\
\text { benefits } \\
\text { (meal } \\
\text { vouchers, } \\
\text { etc) }\end{array}$ & $\begin{array}{l}\text { Training } \\
\text { provided }\end{array}$ & $\begin{array}{l}\text { Measures } \\
\text { to control } \\
\text { labour } \\
\text { costs (paid } \\
\text { breaks } \\
\text { etc) } \\
\end{array}$ & $\begin{array}{l}\text { Measures } \\
\text { to control } \\
\text { non-wage } \\
\text { costs }\end{array}$ & $\begin{array}{l}\text { Using } \\
\text { younger } \\
\text { workers } \\
\text { in place } \\
\text { of older } \\
\text { ones } \\
\end{array}$ & $\begin{array}{l}\text { Investing } \\
\text { in new } \\
\text { capital } \\
\text { equipment }\end{array}$ & $\begin{array}{l}\text { Quality } \\
\text { of } \\
\text { product/ } \\
\text { service }\end{array}$ & prices \\
\hline Insufficient Postcode & 2.93 & 2.91 & 2.90 & 2.93 & 2.95 & 2.98 & 2.99 & 3.05 & 3.00 & 2.98 & 3.05 & 3.21 \\
\hline North East & 2.91 & 2.89 & 2.90 & 2.92 & 2.90 & 2.97 & 2.95 & 3.05 & 2.96 & 3.00 & 3.05 & 3.26 \\
\hline $\begin{array}{l}\text { Yorkshire \& } \\
\text { Humberside }\end{array}$ & 2.93 & 2.91 & 2.88 & 2.92 & 2.94 & 2.98 & 2.97 & 3.03 & 3.00 & 2.99 & 3.06 & 3.26 \\
\hline East Midlands & 2.94 & 2.94 & 2.90 & 2.94 & 2.96 & 2.99 & 2.99 & 3.02 & 2.99 & 3.01 & 3.05 & 3.21 \\
\hline East England & 2.96 & 2.93 & 2.89 & 2.94 & 2.98 & 2.99 & 3.00 & 3.04 & 2.99 & 3.02 & 3.04 & 3.19 \\
\hline London \& South East & 2.95 & 2.95 & 2.93 & 2.97 & 2.97 & 3.00 & 2.99 & 3.03 & 3.01 & 3.02 & 3.06 & 3.17 \\
\hline South West & 2.94 & 2.92 & 2.89 & 2.95 & 2.97 & 3.01 & 3.01 & 3.08 & 3.02 & 3.04 & 3.08 & 3.24 \\
\hline West Midlands & 2.95 & 2.95 & 2.91 & 2.96 & 2.97 & 3.01 & 2.99 & 3.03 & 3.01 & 3.01 & 3.05 & 3.22 \\
\hline North West & 2.93 & 2.90 & 2.89 & 2.96 & 2.98 & 3.02 & 3.02 & 3.07 & 3.02 & 3.02 & 3.08 & 3.25 \\
\hline Wales & 2.92 & 2.91 & 2.86 & 2.94 & 2.95 & 2.98 & 3.02 & 3.11 & 3.01 & 3.01 & 3.08 & 3.27 \\
\hline Scotland & 2.94 & 2.93 & 2.88 & 2.95 & 2.97 & 3.00 & 3.01 & 3.07 & 3.03 & 3.00 & 3.07 & 3.25 \\
\hline Northern Ireland & 2.92 & 2.90 & 2.85 & 2.93 & 2.95 & 3.02 & 2.99 & 3.11 & 3.05 & 3.06 & 3.11 & 3.32 \\
\hline Total & 2.94 & 2.92 & 2.90 & 2.94 & 2.96 & 2.99 & 2.99 & 3.05 & 3.01 & 3.01 & 3.06 & 3.22 \\
\hline
\end{tabular}

Note. Mean values are shown. Responses range from 1 (significant decrease) to 5 (significant increase), with 3 as no change. 